\title{
PENGARUH HEALTH EDUKASI BERBASIS TELENURSING TERHADAP PENINGKATAN PENGETAHUAN DAN KEMAMPUAN PASIEN COVID-19 DALAM MELAKSANAKAN PERAWATAN MANDIRI DIRUMAH
}

\author{
Elly L. Sjattar' ${ }^{1}$ Abdul Majid ${ }^{2}$, Rosyidah Arafah ${ }^{3}$, Yuliana Syam ${ }^{4}$, Indra Gaffar ${ }^{5}$, \\ Akbar Harisa ${ }^{6}$ \\ Email : ellylilianty@unhas.ac.id \\ 1,2,3,4,5,6Faculty of Nursing, Hasanuddin University, Makassar, Indonesia
}

\section{ABSTRACT}

Corona Virus Disease-2019 (Covid-19) is an infectious disease caused by a new type of coronavirus, namely SARS-CoV-2. In the beginning of 2020 WHO had declared a global pandemic for this disease and many infected had no symptoms or were mild so they needed isolation, on the other hand there were still many people who didn't knor about how to self-isolate at home which impacted in the higher transmission rate. This study was aimed to determine the increase in knowledge and abilities of Covid-19 patients regarding care during self-isolation at home. This research is a quantitative study with a pre-experimental approach using purposive sampling technique, the sample in this study were 47 patients who were confirmed positive for Covid-19 who were carrying out self-care at home, willing to be respondents. Health education is carried out using an online method via whatsapp (WA) with booklet media. Data was collected using a questionnaire that had been tested for validity and reliability. Statistical test using t-test. The study showed that there was a significant increase in the knowledge and ability of Covid-19 patients after being given health education about self-care at home. Providing health education online through WA to Covid-19 patients can increase their knowledge and abilities. This research is expected to provide additional information about the health education of Covid-19 patients, especially those who are carrying out self-isolation. For further researchers, in order to examine other variables, such as psychosocial effects and coping mechanisms of Covid-19 patients.

\section{ABSTRAK}

Corona Virus Disease-2019 (Covid-19) adalah penyakit menular yang disebabkan oleh virus corona jenis baru, yaitu SARS-CoV-2. Pada awal tahun 2020 WHO telah mendeklarasikan pandemi global untuk penyakit ini dan banyak yang terinfeksi tidak menunjukkan gejala atau ringan sehingga memerlukan isolasi, di sisi lain masih banyak masyarakat yang tidak mengetahui cara isolasi mandiri di rumah. yang berdampak pada tingkat transmisi yang lebih tinggi. Penelitian ini bertujuan untuk mengetahui peningkatan pengetahuan dan kemampuan pasien Covid-19 tentang perawatan selama isolasi mandiri di rumah. Penelitian ini merupakan penelitian kuantitatif dengan pendekatan pra eksperimen menggunakan teknik purposive sampling, sampel dalam penelitian ini sebanyak 47 pasien terkonfirmasi positif Covid-19 yang sedang melakukan perawatan diri di rumah, bersedia menjadi responden. Edukasi kesehatan dilakukan dengan menggunakan metode online melalui whatsapp (WA) dengan media booklet. Pengumpulan data dilakukan dengan menggunakan kuesioner yang telah diuji validitas dan reliabilitasnya. Uji statistik menggunakan uji-t. Hasil penelitian menunjukkan adanya peningkatan yang signifikan pada pengetahuan dan kemampuan pasien Covid-19 setelah diberikan pendidikan kesehatan tentang perawatan diri di rumah. Pemberian edukasi kesehatan secara online melalui WA kepada pasien Covid-19 dapat meningkatkan pengetahuan dan kemampuannya. Penelitian ini diharapkan dapat memberikan tambahan informasi mengenai pendidikan kesehatan pasien Covid-19 khususnya yang sedang melakukan isolasi mandiri. Bagi peneliti selanjutnya, agar dapat mengkaji variabel lain, seperti efek psikososial dan mekanisme koping pasien Covid-19.

\section{Pendahuluan}

Covid-19 dinyatakan menjadi pandemi global sejak 11 Maret 2020 oleh WHO, dan data WHO pertanggal 16 July 2021 Covid telah menyebar ke 223 negara dengan jumlah kasus terkonfirmasi positif sebanyak 188,655,968 orang dan jumlah pasien meninggal 4,067,517 orang, dimana Amerika Serikat merupakan negara dengan kasus terbanyak disusul Eropa dan Asia tenggara (1).

\section{ARTICLE INFO}

Keywords:

Covid-19; health education; self-care, self-isolation

DOI:

10.24252/kesehatan.v14i2.19548

Kata kunci :

Covid-19; pendidikan kesehatan; perawatan diri; isolasi mandiri 
Penyebaran kasus Covid-19 berlangsung dengan cepat di Indonesia, kasus terkonfirmasi pertama kali dilaporkan sebanyak 2 kasus pada 2 februari 2020 di Depok Jawa Barat, dan kemudian kasus ini meningkat sebanyak 790 kasus per 25 maret 2020 dari 24 Provinsi (2). Data Kementerian Kesehatan Indonesia pertanggal 12 Januari 2021 jumlah terkonfirmasi postitif sebanyak 846,765 kasus dan jumlah pasien meninggal sebanyak 24,645 kasus yang tersebar di 34 provinsi di Indonesia termasuk Sulawesi Selatan (3).

Penyebaran kasus Coronavirus di Indonesia semakin meningkat diseluruh Provinsi. Hal ini menyebabkan pemerintah mengambil tindakan dengan mengeluarkan peraturan terkait dengan pembatasan sosial berskala besar dalam rangka percepatan penanganan Covid-19 yang meliputi peliburan sekolah dan tempat kerja, pembatasan kegiatan keagamaan, dan/atau pembatasan kegiatan di tempat atau fasilitas umum (4). Peraturan ini dikeluarkan berdasarkan himbauan dari (5) bahwa kesehatan publik dan langkah- langkah sosial berkontribusi dalam menghentikan rantai penularan secara individual dengan cara proteksi diri seperti cuci tangan dan menggunakan masker, melakukan physical/social distancing seperti menjaga jarak atau menghindari berkumpul.

Model transmisi Covid-19 terbaru yang dikeluarkan oleh WHO pada 9 Juli 2020 yaitu melalui kontak, droplet, udara, permukaan yang terkontaminasi, fecal-oral, darah, ibu kepada anaknya, hewan ke manusia. Virus corona ini ditularkan oleh orang terinfeksi dengan gejala dan orang terinfeksi tanpa gejala (6).

Data wilayah Sulawesi Selatan berdasarkan website dinas kesehatan provinsi Sulawesi Selatan per 19 Desember 2020 menunjukkan jumlah terpapar Covid-19 di Sulawesi Selatan yang terkonfirmasi positif sebanyak 25.179, sembuh sebanyak 20.584, dan meninggal sebanyak 559 . Kota makassar terkonfirmasi jumlah terpapar yang paling tinggi di Sulawesi Selatan dengan konfirmasi per 19 Desember 2020 pukul 23.59 WITA kasus positif sebanyak 11.369, sembuh 10.367 dan yang meninggal 340 yang tersebar di 43 kelurahan (7).

Pada Tahun 2020 Puskesmas Batua Kota Makassar mengelola pasien Covid-19 sebanyak 553 orang, Sedangkan pada Februari 2021 jumlah terkonfirmasi sebanyak 148 orang (Mandiri 103 orang, Hotel 29 orang dan RS 16 orang). (Laporan tahunan Puskesmas Batua, 2021, Laporan Surveilance). Hal ini menunjukkan masih kurangnya pengetahuan dari pasien tentang perawatan mandiri pasien Covid-19. Cara terbaik untuk memberikan perawatan yang relevan bagi pasien di masa pandemi ini adalah melalui Telemedicine (8).

Telemedicine/Telenursing memanfaatkan teknologi untuk menciptakan inovasi dalam memberikan pelayanan keperawatan dan melakukan praktik keperawatan (9). Pembelajaran jarak jauh dengan model kursus online gabungan mode mikro-video relevan diaplikasikan dalam praktik keperawatan dan efektif mengurangi infeksi silang di masa pandemi COVID-19 (10). Berdasarkan hal tersebut, peneliti tertarik untuk melakukan intervensi berupa health edukasi berbasis telenursing tentang perawatan mandiri dirumah pasien Covid-19 secara online melalui media whatsapp (WA).

\section{Metode Penelitian}

Penelitian ini merupakan penelitian kuantitatif dengan desain pre-eksperimental. Populasinya adalah seluruh pasien yang terkonfirmasi potitif Covid-19 di 24 puskesmas di kota Makassar diantaranya Puskesmas Tamalanrea Jaya, Tamalanrea, Cendrawasih, Mamajang, Jongaya, Andalas, Tabaringan, Jumpandang Baru, Daya, Antara, Batua, Kassi-Kassi, Minasaupa, Toddopuli, Antang, Antang Perumnas, Mangasa, Tamangapa, Bira, Kapasa, Sudiang Raya, Sudiang, Bulurokeng, dan Tamalate. Tehnik sampling yang digunakan adalah purposive sampling sesuai dengan kriteria inklusi yaitu berusia $\geq 17$ tahun, bersedia menjadi responden dan sedang menjalani perawatan mandiri dirumah. Penelitian dilakukan pada bulan April - Juni 2021. Data dianalisis menggunakan SPSS versi 25 dengan uji statistik yang digunakan untuk melihat pengaruh health edukasi terhadap peningkatan pengetahuan dan kemampuan pasien Covid-19 yang melakukan perawatan mandiri dirumah menggunakan uji t-tes. 
Instrumen yang digunakan ada 3 macam yaitu: 1) kuesioner A untuk mengumpulkan data karateristik responden, 2) kuesioner B untuk mengukur tingkat pengetahuan responden tentang perawatan mandiri pasien Covid-19 dirumah yang terdiri dari 15 item pertanyaan dan 3) kuesioner $C$ untuk mengukur kemampuan responden dalam melakukan perawatan mandiri dirumah sebanyak 10 item pertanyaan. Untuk kuesioner Pengetahuan dan kemampuan dibuat sendiri oleh tim peneliti dan telah dilakukan uji validitas dan realibilitas dan ditemukan nilai $\mathrm{r}$ hitung > daripada $\mathrm{r}$ tabel untuk uji validitasnya, sedangkan untuk uji reliable diperoleh nilai $\alpha$ cronbach 0.967 untuk variabel pengetahuan dan 0.940 untuk variabel kemampuan, sehingga untuk instrument ini dapat dikategorikan valid dan reliable. Sebelum memulai penelitian, informed consent telah diberikan kepada responden. Izin etik penelitian didapatkan dari Komisi Etik Penelitian Fakultas Kesehatan Masyarakat Universitas Hasanuddin No. 3401/UN4.14.1/TP.02.02/2021.

\section{Hasil dan Pembahasan}

Penelitian ini tentang pengaruh health edukasi berbasis telenursing pasien Covid-19 dalam melaksanakan perawatan madiri di rumah yang dilaksanakan pada April - Juni 2021.

Tabel 1.

Distribusi Frekuensi dan Persentase berdasarkan data demografi pasien Covid-19 yang melaksanakan perawatan mandiri di rumah.

\begin{tabular}{lcc}
\hline Karakteristik & Mean \pm SD & Min-Maks \\
\hline Umur & $34.04 \pm 12.339$ & $17-63$ \\
\hline Karakteristik & $\mathbf{N}$ & $\mathbf{\%}$ \\
\hline Jenis kelamin & & \\
$\quad$ Laki-laki & 22 & 46.8 \\
$\quad$ Perempuan & 25 & 53.2 \\
Pekerjaan & & \\
PNS/Polri & 8 & 17 \\
Pegawai Swasta & 14 & 29.8 \\
Lain-lain/Freelance & 6 & 12.8 \\
IRT/Tidak Bekerja & 19 & 40.4 \\
Pendidikan & & \\
Sarjana & 18 & 38.3 \\
SMA & 25 & 53.2 \\
SMP & 3 & 6.4 \\
SD & 1 & 2.1 \\
Keluhan & & \\
Tanpa Keluhan & 14 & 29.8 \\
Demam & 19 & 40.4 \\
Batuk & 4 & 8.5 \\
Demam dan Batuk & 10 & 21.3 \\
\hline
\end{tabular}

Tabel 1 menjelaskan distribusi responden berdasarkan umur, jenis kelamin, pekerjaan, Pendidikan dan keluhan yang dialami pasien Covid-19 yang menjalani isolasi mandiri dirumah. Hasil menunjukkan bahwa rata-rata responden berumur 34.04 tahun, sebagian besar berjenis kelamin perempuan yang menjalani isolasi mandiri dirumah karena Covid-19 yaitu sebanyak 25 orang (53.2\%). Selain itu, Sebagian besar responden tidak bekerja atau ibu rumah tangga sebanyak 19 orang (40.4\%), tingkat Pendidikan terbanyak adalah SMA 25 orang (53.2\%). Pada 
Pengaruh Health Edukasi Berbasis Telenursing Terhadap Peningkatan Pengetahuan dan Kemampuan Pasien Covid-19 dalam Melaksanakan Perawatan Mandiri di Rumah

tabel ini juga memperlihatkan keluhan yang banyak dialami oleh pasien Covid-19 adalah demam 19 orang (40.4\%).

\section{Tabel 2.}

Pengaruh health edukasi terhadap peningkatan pengetahuan dan kemampuan psien Covid-19 tentang perawatan mandiri di rumah

\begin{tabular}{cccccc}
\hline \multirow{2}{*}{ Variabel } & \multicolumn{4}{c}{ Intervensi } & \multirow{2}{*}{ p-Value * } \\
\cline { 2 - 5 } & \multicolumn{3}{c}{ Pre } & Post & \\
\cline { 2 - 5 } & Mean \pm SD & Min-Max & Mean \pm SD & Min-Max & \\
\hline Tingkat Pengetahuan & $9.64 \pm 1.566$ & $7-13$ & $13.77 \pm 1.183$ & $10-15$ & 0.000 \\
Tingkat Kemampuan & $23.02 \pm 2.996$ & $17-31$ & $31.91 \pm 4.232$ & $25-40$ & 0.000 \\
\hline
\end{tabular}

*Uji t-tes

Tabel 2 menunjukkan rata-rata tingkat pengetahuan responden sebelum dilaksanakan health edukasi berbasis telenursing melalui WA adalah 9.64 dengan standar deviasi 1.566, sedangkan untuk kemampuan responden dalam melakukan perawatan mandiri dirumah memperoleh ratarata 23.02, dengan standar deviasi 2.996. Setelah pelaksanaan health edukasi berbasis telenursing melalui WA diperoleh hasil rata-rata pengetahuan responden 13.77 dengan standar deviasi 1.183 dan kemampuan responden memperoleh nilai rata-rata 31.91 dengan standar deviasi 4.232. hasil penelitian juga menunjukkan bahwa terdapat peningkatan tingkat pengetahuan dan kemampuan responden tentang perawatan mandiri di rumah pasien Covid-19 $(\mathrm{p}<0.05)$.

\section{Gambaran responden yang melaksanakan isolasi mandiri}

Selama masa pandemi Covid-19 pemerintah menginstruksikan kepada masyarakat bahwa perlunya isolasi mandiri bagi orang yang terkonfirmasi positif Covid-19 dan tidak memiliki gejala atau memiliki gejala yang ringan sebagai upaya pencegahan penyebaran Covid-19. Isolasi mandiri adalah protokol yang mewajibkan setiap orang untuk tinggal di dalam rumah atau tempat tinggal masing-masing sambil melakukan upaya pembatasan fisik dengan orang lain 11.

Pada penelitian ini mayoritas responden merupakan kategori dewasa sehingga hal tersebut membuat pesan edukasi lebih mudah ditangkap oleh responden. (Notoatmojo, 2012) mengemukakan bahwa umur seseorang berkaitan erat dengan tingkat pengetahuan dan hal tersebut dapat mempengaruhi kemampuan orang tersebut. Hal ini mempengaruhi pada daya tangkap dan pola pikir seseorang, dimana semakin bertambah umur maka semakin berkembang pula daya tangkap dan pola pikirnya (12).

Tingkat pendidikan terbanyak pada responden dalam penelitian ini adalah SMA 25 orang (53.2\%). Pendidikan merupakan salah satu faktor yang berhubungan dengan daya tangkap seseorang terhadap materi dan konten edukasi sehingga hal ini sangat mempengaruhi proses pemahaman seseorang terhadap materi edukasi yang diberikan. semakin tinggi pendidikan seseorang maka semakin mudah pula dalam menerima informasi dan sebaliknya seseorang yang memiliki tingkat pendidikan rendah maka akan menghambat dalam penerimaan informasi dan nilai-nilai yang baru diperkenalkan (13)

\section{Peningkatan Pengetahuan responden yang melaksanakan isolasi mandiri}

Penelitian ini menggunakan metode health edukasi dengan pendekatan telenursing melalui WA sebagai bentuk pencegahan penyebran Covid-19 dan aturan pemerintah tentang pemberlakuan pembatasan kegiatan masyarakat (PPKM) yang berlaku di seluruh Indonesia. Edukasi secara online dapat menunjang proses pembelajaran seseorang dengan memanfaatkan teknologi (14). Pemberian informasi kesehatan yang akurat dan terkini melalui media sosial telah dapat membantu upaya promosi kesehatan yang berbasis sosial serta kemudahan dalam mengakses informasi yang dibutuhkan masyarakat (15). 
Faktor yang tidak kalah penting dalam proses pemberian informasi adalah media edukasi. Melalui media informasi, penyebaran informasi kesehatan bisa dilakukan dengan mudah dan cepat. Media informasi yang baik ialah media yang dapat memberikan informasi kesehatan atau pesan kesehatan sesuai dengan minat dan kebutuhan, sehingga dapat mempengaruhi perilaku kesehatan masayarakat (16). Pada penelitian ini media yang digunakan adalah booklet yang dilengkapi dengan gambar yang bertujuan untuk mempermudah responden menyerap informasi yang diberikan. Hal ini dapat dilihat pada tabel 2 yang memperlihatkan terjadinya peningkatan pengetahuan responden setelah diberikan health edukasi memiliki perubahan bermakna. Hal ini sesuai dengan penelitian sebelumnya yang melakukan pelatihan perawatan kaki kepada perawat dan kader Kesehatan di makassar terdapat perubahan tingkat pengetahuan setelah diberikan pelatihan $\mathrm{p}=0.000$ (17).

\section{Peningkatan Kemampuan responden yang melaksanakan isolasi mandiri}

Kemampuan merupakan salah satu unsur yang berkaitan erat dengan pengetahuan maupun keterampilan yang dapat diperoleh dari pendidikan, pelatihan dan suatu pengalaman. Kemampuan (abilities) seseorang akan turut serta menentukan perilaku dari orang tersebut (18).

Tujuan utama dari health edukasi adalah terjadi perubahan perilaku melalui perbaikan pada pengetahuan, sikap dan praktik (mendapatkan akses informasi kesehatan, mempergunakan informasi) sehingga pada akhirnya digunakan untuk mempertahankan atau meningkatkan kesehatannya. (19) menyatakan bahwa pendidikan (edukasi) kesehatan dapat meningkakan pengetahuan, sikap dan keterampilan masyarakat tentang penyakit yang sedang dihadapi.

Penelitian ini memperlihatkan terjadinya peningkatan kemampuan pasien Covid-19 tentang perawatan mandiri dirumah setelah dilakukan health edukasi $(\mathrm{p}=0.000)$. Hal tersebut sejalan dengan penelitian sebelumnya oleh (20) yang mengemukakan bahwa terjadi peningkatan kemampuan manajemen diri DM setelah dilakukan pelatihan tentang pengelolaan diet. Hal serupa dilaporkan oleh (21) bahwa terdapat peningkatan efikasi diri pasien setelah dilakukan intervensi edukasi terpadu pasien pasca operasi penggantian sendi panggul dan sendi lutut. (22) melaporkan hal yang berbeda, pada penemuannya diperoleh pengetahuan dan sikap responden tentang Covid-19 termasuk dalam kategori baik, namun pada praktik khususnya Tindakan pencegahan diperoleh hasil yang kurang memuaskan. Hal serupa dilaporkan oleh (23) yang menyatakan bahwa pengetahuan tentang pencegahan Covid-19 diperoleh hasil dalam kategori baik, sedangkan untuk tindakan pencegahan Covid-19 mayoritas responden berada dalam kategori cukup. Diperlukan strategi untuk mengimplementasikan intervensi health edukasi pada pasien Covid-19 yang melaksanakan isolasi mandiri dirumah dengan meningkatkan pelaksanaan monitoring setelah pelaksanaan health edukasi sehingga pasien lebih termotivasi dan dapat sembuh lebih optimal.

\section{Kesimpulan}

Penelitian menunjukkan bahwa terdapat peningkatan pengetahuan dan keterampilan pasien Covid-19 yang melaksanakan isolasi mandiri tentang perawatan mandiri dirumah setelah dilakukan health edukasi secara online melalui whatsapp. Penelitian ini diharapkan dapat menjadi informasi tambahan terkait perawatan mandiri pasien covid selama melaksanakan isolasi dirumah. Peneliti selanjutnya, dapat melihat variabel lain, seperti efek psikososial dan mekanisme koping pasien Covid-19 selama melaksanakan isolasi mandiri.

\section{Daftar Pustaka}

1. WHO. WHO Coronavirus (COVID-19) Dashboard. In 2021. p. 1-6.

2. Kemenkes R. Pedoman Pencegahan dan Pengendalian Corona Virus Disease (Covid-19). Vol. 5, Kementrian Kesehatan Republik Indonesia. 2020. 1-214 p.

3. Kemenkes R. Situasi Terkini Perkembangan Coronavirus Disease 2019 (COVID-19) [Internet]. 2021. p. 1-6. Available from: https://infeksiemerging.kemkes.go.id/situasiinfeksi-emerging/situasi-terkini-perkembangan-coronavirus-disease-covid-19-16-mei- 
Pengaruh Health Edukasi Berbasis Telenursing Terhadap Peningkatan Pengetahuan dan Kemampuan Pasien Covid-19 dalam Melaksanakan Perawatan Mandiri di Rumah

2021

4. Kemenkes R. Surat Edaran No. HK.0201/MENKES/202/2020/Tentang Protokol Isolasi Diri Sendiri Dalam Penanganan CoronaVirus Disease (Covid-19) [Internet]. 2020. p. 1-4. Available from: https://covid19.kemkes.go.id/download/SE_MENKES_202_2020_protokol_isolasi_diri_COV ID.pdf

5. WHO. Clinical management of severe acute respiratory infections when novel coronavirus is suspected: What to do and what not to do. In: Who [Internet]. 2020. p. 1-12. Available from:

http://www.who.int/csr/disease/coronavirus_infections/InterimGuidance_ClinicalManage ment_NovelCoronavirus_11Feb13u.pdf

6. WHO. Home care for patients with suspected or confirmed COVID-19 and management of their contacts. In: World Health Organization [Internet]. 2020. p. 1-9. Available from: https://www.who.int/publications-detail/home-care-for-patients-with-suspected-novelcoronavirus-(ncov)-infection-presenting-with-mild-symptoms-and-management-ofcontacts

7. Dinkes PS-S. Data pantauan Covid-19 di Sulawesi Selatan. In 2021. p. 1-10.

8. Tinelli G, Sica S, Guarnera G, Pitocco D, Tshomba Y. Wound Care during COVID-19 Pandemic. Ann Vasc Surg [Internet]. 2020;68:93-4. Available from: https://doi.org/10.1016/j.avsg.2020.06.044

9. Kotsani K, Antonopoulou V, Kountouri A, Grammatiki M, Rapti E, Karras S, et al. The role of telenursing in the management of Diabetes Type 1: A randomized controlled trial. Int J Nurs Stud [Internet]. 2018;80(December 2017):29-35. Available from: https://doi.org/10.1016/j.ijnurstu.2018.01.003

10. Zhou T, Huang S, Cheng J, Xiao Y. The distance teaching practice of combined mode of massive open online course micro-video for interns in emergency department during the COVID-19 epidemic period. Telemed e-Health. 2020;26(5):584-8.

11. Siregar R, Gulo ARB, Sinurat LRE. Edukasi Tentang Upaya Pencegahan Covid-19 Pada Masyarakat Di Pasar Sukaramai Kecamatan Medan Area Tahun 2020. J Abdimas Mutiara [Internet]. 2020;1(2):191-8. Available from: http://e-journal.sarimutiara.ac.id/index.php/JAM/article/view/1490

12. Ayuningtiyas PY. Gambaran Peran Keluarga Dalam Merawat Anggota Keluarga Yang Mengalami Osteoartritis Di Desa Jetis. Skripsi. 2019;

13. Sumiati, Asra. Metode Pembelajaran. Bandung: CV Wacana Prima; 2010.

14. Bower M. Technology-mediated learning theory. Br J Educ Technol. 2019;50(3):1035-48.

15. Leonita E, Jalinus N. Peran Media Sosial Dalam Upaya Promosi Kesehatan: Tinjauan Literatur. INVOTEK J Inov Vokasional dan Teknol. 2018;18(2):25-34.

16. Aprida C, Rahman MA, Rachman WA. Edukasi Kesehatan Melalui Program Acara Kesehatan di Media Massa (TVRI Sulawesi Selatan). J MKMI. 2015;16-22.

17. Sjattar EL, Majid A, Yusuf S, Syam Y, Nurdin N. Effect of Foot Care Health Training Towards Nurses and Health Volunteers Ability in Performing Foot Care on Diabetes in Batua Health Center, Makassar. J Heal Sci Prev. 2019;3(3S):79-83.

18. Muazansyah I. Pengaruh Kemampuan Kerja (Work Ability) Dan Kualitas Kerja (Work Quality) Terhadap Kualitas Pelayanan Publik Didinas Sosial Kabupaten Bangkalan. Apl Adm Media Anal Masal Adm. 2018;21(1):48.

19. Mardhiah A, Abdullah A, Hermansyah. Pendidikan Kesehatan Dalam Peningkatan Pengetahuan, Sikap Dan Keterampilan Keluarga Dengan Hipertensi - Pilot Study. J Ilmu Keperawatan [Internet]. 2015;3(2):111-21. Available from: http://jurnal.unsyiah.ac.id/JIK/article/view/5310

20. Luawo HP, Sjattar EL, Bahar B, Yusuf S, Irwan AM. Aplikasi e-diary DM sebagai alat monitoring manajemen selfcare pengelolaan diet pasien DM. NURSCOPE J Penelit dan Pemikir Ilm Keperawatan. 2019;5(4):32-8.

21. Malinga M, Sjattar EL, Syahrul S. Efektifitas Edukasi Terpadu dalam Meningkatkan Efikasi Diri Pasien Pasca Operasi Total Hip dan Knee Replacement di Rumah Sakit. J Keperawatan 
Pengaruh Health Edukasi Berbasis Telenursing Terhadap Peningkatan Pengetahuan dan Kemampuan Pasien Covid-19 dalam Melaksanakan Perawatan Mandiri di Rumah

Muhammadiyah [Internet]. 2019;4(1):1-6. Available from: http://journal.umsurabaya.ac.id/index.php/JKM

22. Salman M, Mustafa ZU, Asif N, Zaidi HA, Hussain K, Shehzadi N, et al. Knowledge, attitude and preventive practices related to COVID-19: a cross-sectional study in two Pakistani university populations. Drugs Ther Perspect [Internet]. 2020;36(7):319-25. Available from: https://doi.org/10.1007/s40267-020-00737-7

23. Goni CS, Rumayar AA, Tucunan AAT. Gambaran Perilaku Masyarakat Terhadap Pencegahan Corona Virus Disease 19 (Covid-19) Di Kelurahan Matani 1 Kecamatan .... Kesmas [Internet]. 2021;10(2):168-75. Available from: https://ejournal.unsrat.ac.id/index.php/kesmas/article/view/32381 